\title{
Exploring the Effect of Perceived Service Quality on Customers Satisfaction: A Study of Banking Sector in Jordan
}

\author{
Niveen M. Al-Sayyed (Corresponding author) \\ Dept. of Business Management, The University of Jordan \\ PO Box 11942, Amman-Jordan \\ Tel: 962-798514778 E-mail: n.alsayed@ju.edu.jo
}

Taghrid S. Suifan

Dept. of Business Management, The University of Jordan

PO Box 11942, Amman-Jordan

E-mail: t.suifan@ju.edu.jo

Afnan R. Alawneh

Dept. of Business Management, The University of Jordan

PO Box 11942, Amman-Jordan

E-mail: a.alawneh@ju.edu.jo

Received: Jan.13, $2015 \quad$ Accepted: Jan. 29, $2015 \quad$ Published: January 29, 2015

doi:10.5296/jmr.v7i1.6966

URL: http://dx.doi.org/10.5296/jmr.v7i1.6966

\begin{abstract}
This study aims at investigating the effect of perceived service quality on customer satisfaction in the banking sector in Jordan. Service quality is studied within a set of different aspects based on SERVQUAL model.

Respondents are chosen from a range of varying demographic features using random sampling. SERVQUAL questionnaires were distributed among 270 customers of different banks. 225 questionnaires were considered valid for analysis constituting an 83\% final
\end{abstract}




\section{Macrothink}

Journal of Management Research

ISSN 1941-899X 2015, Vol. 7, No. 1

response upon which the analysis has been executed. Analysis was performed using SPSS version 20.

The results showed a significant association between perceived service quality -expressed by its five dimensions- and overall customer satisfaction.

Keywords: Perceived service quality, Customer satisfaction, SERVQUAL, Banking sector in Jordan 


\section{Introduction}

In today's competitive environment, an organization's facility to deliver high quality services that result in satisfied customers is said to be the key to a sustainable competitive advantage (Shemwell et al., 1998). Customer satisfaction has a positive effect on an organization's profitability. The more customers are satisfied with products or services offered, the greater the chances for success as customer satisfaction leads to repeat purchase, brand loyalty, and positive word of mouth marketing (Zairi, 2000). Satisfied customers are more likely to repeat buying products or services. They will also tend to say good things and to recommend the product or service to others. On the other hand, dissatisfied customers respond differently. Dissatisfied customers may try to reduce the dissonance by abandoning or returning the product, or they may try to reduce the dissonance by seeking information that might confirm its high value (Kotler, 2000).

Evidence is growing on placing a high priority on customer satisfaction which is critical to improved organizational performance in a global market scenario. With better understanding of customers' perception, companies can determine the actions required to meet their customers' needs. They can identify their own strengths and weaknesses, where they stand in comparison to their competitors and they can chart out path for future progress and improvement (Santhiyavalli, 2011).

Commercial banks play a vital role in the social economic development process in Jordan by providing financial products and services. Recently competiveness in the banking sector has been increasing. The technological revolution has directly impacted on world banking activities and the spread of computer access, along with innovation in banking services and methods, has enhanced speed in performance, customer satisfaction and confidence in banking systems (Abbad., et al 2012).

An essential requirement for competitiveness and staying in business is satisfied customer (Goetsch \& Davis, 2013). Moreover, because Service Quality has direct positive impact on customers affecting their satisfaction (Gremler \& Gwinner, 2000), efforts are being taken to improve their competitiveness through enhanced service quality, which is vital for keeping their customers well contented and satisfied (Santhiyavalli, 2011).

In addition, service quality is consistently viewed in the literature as a unique construct of customer satisfaction. Therefore, it is very important to assess the customers' perception of service quality and the degree of satisfaction with different services and products provided by banks.

Banks also are continually looking at ways to improve their internal efficiency, and in turn, are trying to expand the utilization of their cheapest delivery methods. These have given a wider choice to consumers, competitive pricing of products and easier access to services. Therefore, banks are under a tremendous pressure to improve their services (Mishra, 2010).

The main objectives of this paper are:

1. To examine the effects of perceived service quality on customer satisfaction.

2. To explore ways in which service quality can be implemented in Jordanian banks. 


\section{Literature Review}

Today, the quality of goods and services perceived by customers are highly important, it has become an obligation for firms to supply quality goods and services into the market. So it is necessary to follow customers' expectations closely and promptly take the essential steps to meet them (Çırpın \& Sarıca, 2014). In addition, the customer is the center of attention and customer service is the distinguishing factor (Jham \& Khan, 2008). Furthermore, quality is one of the key organizational innovations of the twentieth century, which has contributed a methodically grounded methodology to focus attention on customers (Lillrank, 2003).

Premium service quality is a key to gain a competitive advantage in services industry.

The satisfaction level of customers is dependent on their perception of service quality and the trust in the service provider (Ismail et al., 2006). Particularly in banking industry, premium service quality plays a pivotal role for customers in evaluating the performance of a service provider and is the key to gain customer satisfaction and customer loyalty. A bank can gain competitive advantage and build long term relationship with its customers by providing premium quality services (Jham \& Khan, 2008).

Numerous studies have tried to determine the relationship between service quality and customer satisfaction. For example Uddin \& Akhtar, (2012) indicate that service quality has a positive direct impact on customer satisfaction in a mass service industry (i.e., banking industry). Kuo \& Ye (2009) analyzed the relationship between service quality, corporate image, satisfaction and loyalty in a sample of students from a vocational training center in Taiwan. The study of Kuo \& Ye (2009) showed that both service quality and corporate image have a direct and significant effect on student satisfaction.

Mishra (2010) identifies the factors that are responsible for the satisfaction of the customers, and also enables the assessment of the influencing power of these factors. These factors such as core services of the bank, customer convenience being provided, customers' continuation factors, resolution of customers' problems, interest-related policies adopted, and charges levied by the bank. This, in turn, would help in the enhancement of the relationship between the retail banks and their customers, and thus aid the decision makers of these banks to identify the major factors that determine the satisfaction of their customers. Yeh (2013) investigated the impact of customer advocacy on customer perceived value. The results indicated that customer advocacy positively relates to customer trust and satisfaction, directly and positively relate to customer perceived value, and customer empowerment and organizational innovation directly and positively relate to customer advocacy.

The study of Santhiyavalli (2011) conducted to evaluate the service quality of State Bank of India by identifying the major factors responsible for customer satisfaction. To support the objective of the study, SERVQUAL technique was adopted, the results indicates that among five dimensions 'Reliability', 'Responsiveness', 'Empathy' and 'Tangibility' are the major factors responsible for customer satisfaction.

Zaeim \& Abednyia (2011) studied the perceive service quality in the Islamic Banking System in Malaysia which showed that there is a gap between customer expectation and perception concerning service quality dimensions. By measuring this gap we can find the level of customers' perceive service quality. Gil et al. (2007) exhibited that services encountered 
directly and significantly affect the perceived service value which is the final antecedent to customer satisfaction in the banking industry.

The customer's perception of what is created and delivered should be established and considered when the firm defines its value proposition (Payne \& Holt, 2001). Customers perceive value according to their personal judgment of what they get and what they give. The components of perceived value may be differentially weighted depending on the consumer. Analyzing perceived value from the perspective of the customer is appropriate because the success of a firm in creating value for customers depends largely on the ability of the firm to identify the type of value customers expect (DeSarbo et al., 2001)

Customer expectation revolves around their conviction about the products and services that they receive from the organization and company that serves them. It is comprehended as the reference point against which the performance of the service provided is judged. This understanding is imperative for marketers because customers compare the performance or quality of the services received and determines these as the reference points when they experience and evaluate the service quality (Zeithaml et al., 2006).

Yeh, (2013) argues that although the service itself adds value, the enhancement of customer-perceived value relies on the firm actively communicating customer advocacy capabilities to the customers by promoting customer trust and satisfaction. Firms focus on gathering extensive data about their customers, and then use the information to segment and personalize their offerings and marketing communications. We believe that service firms facilitate the creation and sharing of knowledge, competencies, and practices through open-mindedness to shape customer advocacy. Furthermore, the level of previous customer experience with certain services by other firms can impact on customers' perception of service quality (Zeithaml, 1988;).

From the preceding literature review, it is clear that a positive relationship exists between perceived service quality and customer satisfaction. The purpose of this paper is to investigate this relationship in the Jordanian Banking Sector.

\section{Theoretical Background}

Many studies focused on exploring interrelationships between service quality and customer satisfaction. It is generally accepted that high service quality results in customer satisfaction and other desirable customer behaviors such as loyalty, greater willingness to make a recommendation to someone else, reduction in complaints and an improved customer retention rate (Levesque and McDougall, 1996; Zeithaml et al., 1996, Danaher, 1997).

Many business organizations in the world have been elevating the role of the customer to that of a key stakeholder. Customers are viewed as a group whose satisfaction with the enterprise must be incorporated in strategic planning efforts (Santhiyavalli, 2011).

The emergence of service quality and its assessment has attracted the attention of numerous researchers in the past two decades or so (Santhiyavalli, 2011).

Perceived service quality looks at the difference between customers' performance and expectation; which results in measurement of perceived service quality by highlighting the gap between them. 


\subsection{Dimensions of Service Quality}

A number of researchers have provided lists of quality determinants, but the most commonly known determinants emanate from Parasuraman and his colleagues, who found five dimensions of service quality, namely, Tangibility, Reliability, Responsiveness, Assurance and Empathy (Parasuraman et al.,1988; Zeithaml et al., 1990., Santhiyavalli, 2011). A brief explanation of these dimensions is given below

- Reliability: This item refers to the ability to perform promised services at the promised time, accurately, and dependably (Arizon, 2010). This means that services should be available as soon as customers expect to get the service, thus bankers should not misuse the cardholder information and there should be frequent update of new technologies. (Santhiyavalli, 2011).

- Assurance: This dimension addresses knowledge and courtesy of employees and their ability to convey trust and confidence (Arizon, 2010). If the employees of financial institutions display trustworthy behavior, the satisfaction level of customers can be enhanced significantly. It may also positively influence repurchase intension of customers (Ndubisi, 2006).

- Tangibles: This item refers to the appearance of physical facilities, equipment, employees, and communication materials (Arizon, 2010). In simple words tangibles are about creating foremost impressions. All organizations desire that their consumers get an exceptional and positive foremost impression. Focusing on this particular dimension will help them to gain maximum benefit. (Swar \& Sahoo, 2012).

- Responsiveness: Responsiveness means the willingness of the organization to assist customers and provide prompt services (Arizon, 2010). It can be measured by the amount of time needed to deal with customers' reported problems and the response duration once the customer filed a service request (Santhiyavalli, 2011).

- Empathy: In a word, empathy refers to individual attention and employees' understanding of each customer's needs (Arizon, 2010). Empathy creates an emotional relationship with customer, providing customer a touch of importance for business. This leads to retention and creation of new customer's pool (Wieseke et al., 2012).

\subsection{Customer Satisfaction}

Forward looking companies are finding value in directly measuring and tracking customer satisfaction (CS) as an important strategic success indicator (Santhiyavalli, 2011). Customer satisfaction is considered to be an important factor in the success of any organization and its continuity in the market place. It is generally argued that, if customers are satisfied with a particular product or service that they have used then they are likely to engage in a repeat purchase and also may be willing to try a line extension (Abdullah \& Kassim, 2009).

To ensure customer satisfaction, it must be renewed with every new purchase. This cannot be accomplished if quality, even though it is high, is static. Satisfaction implies continual improvement. Continual improvement is the only way to keep a customer satisfied and loyal (Goetsch, \& Davis 2013). Moreover, satisfied customers also are likely to tell others of their favorable experiences and, thus, engage in positive word of mouth. An important factor that may lead to customer satisfaction is the level of Service Quality provided by the 
organization. Customer satisfaction depends on the quality of the service or product offered, which means service quality is related to satisfaction but not equivalent to it (Abdullah \& Kassim, 2009).

Liu et al. (2008) suggested the following criteria for measuring the satisfaction level of customers regarding purchase and subsequent consumption of goods or services:

- Satisfaction: The perception developed by the customers that the goods or services are acceptable or tolerable.

- Content: The features of goods or services and the underlying benefits gives customer a positive consumption experience.

- Relived: The alleviation of the negative state of customers' mind of by the goods or services provided.

- Novelty: The goods or services bring freshness and excitement in customers.

- Surprise: The amazement and unexpected pleasure brought to people by goods or services consumed.

\section{Methodology}

The main goal of this study is to investigate the effect of perceived service quality on customer satisfaction of banking sector in Jordan. For this purpose primary data is collected using SERVQUAL questionnaire, a scale developed by Parasuraman et al. (1988). It is considered a reliable service quality measurement model. The questionnaire consists of two sections. The first section contains items regarding independent variable which measures perceived service quality through five dimensions (reliability, assurance, tangibles, empathy, and responsiveness), and items regarding dependent variable which measures customer satisfaction. The second section contained questions on the demographic characteristics of the subjects.

In this study data is collected from 225 bank customers. The data is then entered in Statistical Package for Social Sciences (SPSS 20) for analysis. Regression and multiple regression analysis are done to analyze data.

\subsection{Research Model}

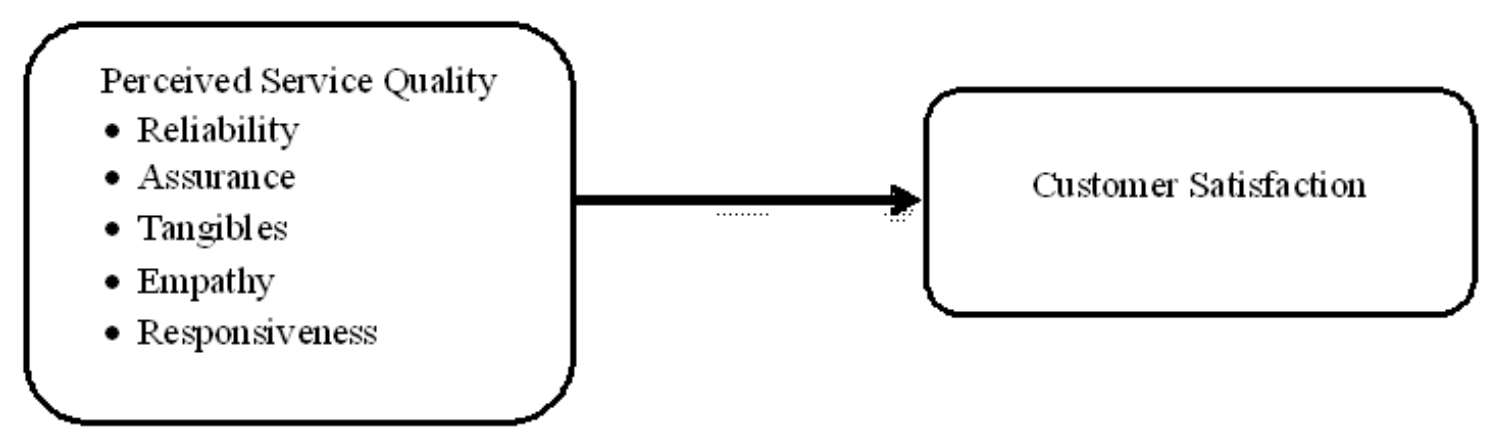


4.2 Hypothesis

\subsubsection{Null Hypothesis}

H0: There is no statistically significant relationship between perceived service quality and Customer satisfaction

\subsubsection{Sub Hypotheses}

Sub H01: There is no statistically significant relationship between Reliability and Customer satisfaction

Sub H02: There is no statistically significant relationship between Assurance and Customer satisfaction.

Sub H03: There is no statistically significant relationship between Tangibles and Customer satisfaction.

Sub H04: There is no statistically significant relationship between Empathy and Customer satisfaction.

Sub H05: There is no statistically significant relationship between Responsiveness and Customer satisfaction.

\subsection{Research population}

The research population consists of national banks in Jordan. To develop an appropriate sample from this population, the researchers used stratified random sampling method as a procedure in order to obtain a desired representation of the entire population (O' Neil, 2010). 270 questionnaires were distributed; 225 questionnaires were considered valid to the analysis. The research sample included only the national banks. Foreign banks were excluded. According to Central Bank of Jordan in 2014, the total number of national banks in Jordan is 16 commercial and Islamic banks (CBJ, 2014).

\subsubsection{Respondent's demographic profile}

The respondents were asked to give information about their gender, age and occupation, table (1) represents the number and the percentages of respondents belonging to each group. 
Table (1). Demographics

\begin{tabular}{|c|c|c|c|}
\hline Demographics & Category & $\begin{array}{c}\text { No. of respondents in } \\
\text { category }\end{array}$ & Percentage \\
\hline \multirow{3}{*}{ Gender } & Male & 160 & 71.1 \\
\cline { 2 - 4 } & Female & 65 & 28.9 \\
\cline { 2 - 4 } & Total & 225 & 100.0 \\
\hline \multirow{4}{*}{ Age } & $21-25$ & 28 & 12.4 \\
\cline { 2 - 4 } & $26-30$ & 55 & 24.4 \\
\cline { 2 - 4 } & $31-35$ & 74 & 32.9 \\
\cline { 2 - 4 } & $36-40$ & 43 & 19.1 \\
\cline { 2 - 4 } & 41 and above & 25 & 11.1 \\
\hline \multirow{5}{*}{ Occupation } & Total & 255 & 100.0 \\
\cline { 2 - 4 } & Salaried & 120 & 53.3 \\
\cline { 2 - 4 } & Business & 57 & 25.3 \\
\cline { 2 - 4 } & Student & 48 & 21.3 \\
\hline
\end{tabular}

\subsubsection{Characteristics of the sample}

Table (1) shows distribution of the research respondents who respond to the questionnaire according to gender, the percentage of females was $28.9 \%$ while the percentage of males was $71.1 \%$. Males represented the majority of the study sample. According to the age variable, the percentage of customers between the age of $31-35$ was $32.9 \%$ (the highest percentage) followed by the category of $26-30$ with the percent of $24.4 \%$ and then the category of $36-40$ with the percentage of $19.1 \%$ and then the category of $21-25$ with the percent of $12.4 \%$. Meanwhile, the lowest percentage was 11.1 represented by the more than 40 years age category. Moreover, the findings indicate that the highest percentage of $(53.3 \%)$ was for salaried category followed by percentage of $(25.3 \%)$ for business, while the lowest percentage of $48(21.3 \%)$ was for student category.

4.3.3 Relative importance of each dimension of SQ according to the mean of the sample results

Mean of the 5-point Likert scale used in this study equals 3, $(1+2+3+4+5 / 5=3),(3)$ meaning that 3 represents a medium level, less than 3 is a low level, and greater than 3 is a high level. 
Table (2). Relative Importance for Variables

\section{Independent Variable}

\begin{tabular}{|l|l|l|l|}
\hline Factor & Mean & Standard Deviation & Rating \\
\hline TANGIBLES & 3.30 & 1.19 & Relatively important \\
\hline RELIABILITY & 3.20 & 1.21 & Relatively important \\
\hline RESPONSIVENESS & 3.08 & 1.19 & Relatively important \\
\hline ASSURANCE & 3.05 & 1.14 & Relatively important \\
\hline EMPATHY & 3.21 & 1.23 & Relatively important \\
\hline Dependent Variable & 3.22 & 1.21 & Relatively important \\
\hline Satisfaction & &
\end{tabular}

Table (2) illustrates the mean scores of the variables of study, the results showed that the degree of influence for Perceived Service Quality elements used in this study is relatively positive, since the means were higher than 3 and their standard deviations were lower than 1 for all variables.

The results indicate that the mean score of first service quality dimension (Tangibles) is 3.30 with a standard deviation of 1.19. The mean score of tangibles is more than 3 which means customers agree that bank facilities and equipment's, and employees of the bank support customer satisfaction. The standard deviation indicates that there is less variability in the responses as indicated by the standard deviation of tangibles.

Reliability has a mean score and a standard deviation of 3.20, 1.21 respectively. The results indicate that customers agree that banks provide promised services, and perform the right service at the right time. Moreover, there is less variability in the responses.

Responsiveness has a mean score of 3.05 with a standard deviation of 1.19 . These results indicate that customers agree that bank employees' are always willing to serve and help customers.

Assurance has a mean score of 3.08 with a standard deviation of 1.14 . This indicates that customers agree that they feel safe and confidence in their dealings and transactions.

Empathy has a mean score of 3.21 with a standard deviation of 1.23 . The results indicate that customers agree that the banks understand their needs and give them individual attention.

The mean score of customer satisfaction is 3.22 with standard deviation 1.21. The mean score of customer satisfaction shows that customers agree that they are satisfied with the quality of services delivered by their banks.

Consequently, all variables have a high degree of influence on the customer satisfaction. However scores on responsiveness and Assurance are relatively low as compared to other variables.

\subsubsection{Hypotheses testing and findings}

NULL hypothesis: There is no statistically significant relationship between perceived SQ and Customer satisfaction. 
The results of testing of the main hypothesis are demonstrated in tables 3,4 :

Table (3). Model Summary

\begin{tabular}{|l|l|l|l|l|}
\hline Model & R & R Square & Adjusted R Square & Std. Error of the Estimate \\
\hline 1 & $.992^{\mathrm{a}}$ & .984 & .983 & .15661 \\
\hline
\end{tabular}

Table (4). ANOVA

\begin{tabular}{|l|l|l|l|l|l|}
\hline Model & Sum of Squares & df & Mean Square & F & Sig. \\
\hline Regression & 323.646 & 5 & 64.729 & 2638.988 & $.000^{\mathrm{b}}$ \\
Residual & 5.372 & 219 & .025 & & \\
Total & 329.018 & 224 & & & \\
\hline
\end{tabular}

The multiple correlation coefficient $\mathrm{R}=98 \%$ indicates that there is a positive correlation between perceived service quality elements and customer satisfaction; it demonstrates that the independent variables and dependent variable change in the same direction. The multiple correlation coefficients gauge how well the model predicts the observed data.

$\mathrm{R}$ square represents the variability in customer satisfaction. The value of $\mathrm{R} 2=99 \%$ indicates the amount of variations in customer satisfaction that is explained by the perceived service quality. It also means that the higher the service quality is, the higher the customer satisfaction. The adjusted R2 reflects the strength and generalizability of the model.

The (ANOVA) analysis shows that F-ratio $=2638.988$ which is significant at $\mathrm{p}<.05$ (Alpha in this case is significant at .000). This result shows that there is less than a $0.05 \%$ chance that an F-ratio of this value would happen by chance alone. It follows that there is statistically significant effect of service quality (At least one of the variables) on customer satisfaction, thus we reject the null hypothesis and accept the alternative hypothesis which states that there is a relation between perceived services quality level and customer satisfaction. The other part of multiple regression analysis is concerned with testing the effect of each predictor included in the model (that is beta $\beta$ ) on the dependent variable.

Table (5). Coefficients ${ }^{\mathrm{a}}$

\begin{tabular}{|l|r|r|r|r|r|}
\hline \multirow{2}{*}{ Model } & \multicolumn{2}{|c|}{$\begin{array}{c}\text { Unstandardized } \\
\text { Coefficients }\end{array}$} & $\begin{array}{c}\text { Standardized } \\
\text { Coefficients }\end{array}$ & \multicolumn{1}{c|}{ S } & \\
\cline { 2 - 4 } & \multicolumn{1}{|c|}{ B } & Std. Error & \multicolumn{1}{c|}{ Beta } & & \\
\hline (Constant) & $-.052-$ & .033 & & $-1.559-$ & .120 \\
Tangibles & .537 & .056 & .531 & 9.659 & .000 \\
Reliability & .218 & .068 & .219 & 3.185 & .002 \\
Responsiveness & .124 & .034 & .122 & 3.607 & .000 \\
Assurance & .011 & .019 & .011 & .606 & .545 \\
Empathy & .119 & .050 & .121 & 2.394 & .018 \\
\hline
\end{tabular}


Table (5) provides the results of predicting customer satisfaction through the dimensions of service quality, tangibles, reliability, responsiveness, assurance, and empathy. All variables have a significant relationship with customer satisfaction. The regression coefficients of tangibles, reliability, responsiveness, assurance, and Empathy are .537, .218, .124, .011, .119 respectively. For tangibles and reliability $\beta$ equals to $54 \%$ and $22 \%$ respectively compare to the relatively small values of other variables.

We can infer from the values of beta that the variables that have the highest contribution in the model are the tangibles followed by reliability. As shown above all variables of perceived service quality are significant and affect the customer satisfaction except assurance doesn't affect the model when $\mathrm{p}<.05$.

\section{Conclusions}

The main objective of this study is to examine the relation between Perceived Service Quality elements and customer satisfaction. For this purpose, a sample of 270 questionnaires was distributed. The unit of analyses consisted of customers of different banks in Jordan. The study focused on the need for exploring the effect of perceived service quality on customers satisfaction.

Results indicate that service quality and all its dimensions have significant and positive relationship with customer satisfaction. These results are in conformity with the existing literature (Jham \& Khan, 2008; Santhiyavalli 2011; Gil et al., 2007).

The study will be of assistance to the management of banks due to the provision of better insights, thus enabling them to improve the levels of customer satisfaction. Furthermore, Managers should know what customers want and how they become satisfied. Firms should understand the importance of service quality to customers. At the same time, service quality has positive direct influence on customer satisfaction. Therefore, bank managers should develop a systematic program to monitor service quality, perceived value and satisfaction of customers. Bank clients should be informed about the activities of bank management regarding customer satisfaction issues. In this way, companies can better allocate resources to provide better service to their customers.

\section{Recommendations}

The following recommendations are proposed to banking sector in Jordan:

1. Customer satisfaction is an important factor that affects customer loyalty as well as works as that attracts customers to the organization.

2. Periodical market research is important to see if there are any changes on customers' needs, demands, and expectations.

3. Adopting customer oriented culture is very important to ensure high level of customer satisfaction.

4. Adopting competitive edge is very important, in which it delivers innovating-high quality products and services, in order to meet the changing needs and demands of customers. 


\section{References}

Abbad, M., Abed, J., and Abbad, M. (2012). The Development of E-Banking in Developing Countries in the Middle East. Journal of Finance, Accounting and Management, 3(2), 107-123. 8629854

Abdullah, A., and Kassim, N. (2009). Measuring Perceived Service Quality in Qatari Islamic Banks. Journal of International Business and Entrepreneurship Development 4, 1(2), 90-106. http://dx.doi.org/10.1504/JIBED.2009.022531

Abedniya. A, and Zaeim. M (2011). Measuring the Perceive Service Quality in the Islamic Banking System in Malaysia. International Journal of Business and social science, 2(13), 122-135.

Arizon, V. (2010). Service Quality Delivery in the Food and Beverage Service CPUT Theses \& Dissertations.

Çırpın, B. and Sarıca, A. (2014). Measurement of Service Quality in Banking Industry: A Case Study from Turkey. Istanbul University Journal of the School of Business, 43(2), 205-217.

Danaher, P.J. (1997). Using Conjoint Analysis to Determine the Relative Importance of Service Attributes Measured in Customer Satisfaction Surveys. Journal of Retailing, 73(2), 235-60. http://dx.doi.org/10.1016/S0022-4359(97)90005-1

DeSarbo, W.S., Jedidi, K., and Sinha, I. (2001). Customer Value Analysis in a Heterogeneous Market. Strategic Management Journal, 22(9), 845-857. http://dx.doi.org/10.1002/smj.191

G. Santhiyavalli (2011). Customer's Perception of Service Quality of State Bank of India, A Factor Analysis. International Journal of Management \& Business Studies, 1(3), 78-84. http://www.ijmbs.com/13/gsanthivalli.pdf

Gil, S.M., Hudson, S., and Quintana, T.A. (2006). The Influence of Service Recovery and Loyalty on Perceived Service Quality. A Study of Hotel Customers in Spain. Journal of Hospitality and Leisure Marketing, 14(2), 47-68. http://dx.doi.org/10.1300/J150v14n02_04

Goetsch, D., and Davis, S. (2013). Customer Satisfaction. Quality Management for Organizational Excellence. Seventh Edition. Pearson Education, Inc., Upper Saddle River, New Jersey.

Gremler, D.D., and Gwinner, K.P. (2000). Customer-Employee Rapport in Service Relationships. Journal of Service Research, 3(1), 82-104. http://dx.doi.org/10.1177/109467050031006

Ismail, I., Haron, H., Ibrahim, D., and Isa, S. (2006). Service Quality, Client Satisfaction and Loyalty towards Audit Firms: Perceptions of Malaysian Public Listed Companies. Managerial Auditing Journal, 21(7), 738-756. http://dx.doi.org/10.1108/02686900610680521

Jham, V., and Khan, K. (2008). Determinants of Performance in Retail Banking: Perspectives of Customer Satisfaction. Singapore Management Review, 30(2), 35-45. 
Kotler, P. (2000). Designing and Managing Services. Marketing Management. Fourteenth Edition. Pearson Education, Inc., Upper Saddle River, New Jersey.

Kuo, Y., and Y. (2009). The Causal Relationship between Service Quality, Corporate Image and Adults' Learning Satisfaction and Loyalty: A Study of Professional Training Programs in a Taiwanese Vocational Institute. Total Quality Management and Business Excellence, 20(7), 749-762. http://dx.doi.org/10.1080/14783360903037085

Lee, C. (2011). Understanding Bank Service Quality in Customers' Terms: An Exploratory Analysis of Top-Of-Mind Definition. International Journal of Business and Social Science, 2(21), 1-7.

Levesque, T. and McDougall, G.H.G. (1996). Determinants of Customer Satisfaction in Retail Banking. International Journal of Bank Marketing, 14(7), 12-20. http://dx.doi.org/10.1108/02652329610151340

Lillrank P. (2003). The Quality of Information. International Journal of Quality \& Reliability Management, 20(6), 691-703. http://dx.doi.org/10.1108/02656710310482131

Liu, Y., Li, Y., Tao, L., and Wang, Y. (2008). Relationship Stability, Trust and Relational Risk in Marketing Channels: Evidence from China. Industrial Marketing Management, 37(4), 432-446. http://dx.doi.org/10.1016/j.indmarman.2007.04.001

Mishra, A. (2010). Factors Affecting Customer Satisfaction and Their Relative Importance in the Retail Banking Sector: An Empirical Study. The IUP Journal of Management Research, 9(3), 7-23.

Ndubisi, N. O. (2006). A Structural Equation Modelling of the Antecedents of Relationship Quality in the Malaysia Banking Sector. Journal of Financial Services Marketing, 11(2), 131-141. http://dx.doi.org/10.1057/palgrave.fsm.4760033

Payne, A. and Holt, S. (2001). Diagnosing Customer Value: Integrating the Value Process and Relationship Marketing. British Journal of Management, 12(2), 159-182. http://dx.doi.org/10.1111/1467-8551.00192

Santhiyavalli, G. (2011). Customer's Perception of Service Quality of State Bank of India-A Factor Analysis. International Journal of Management \& Business Studies, 1(3), 78-84. http://www.ijmbs.com/13/gsanthivalli.pdf

Sekaran, U., and Bougie, R. (2009). Research Method for Business. A skill building Approach. Fifth Edition. John Wiley \& Sons, Inc.

Shemwell D., Yavas, J.U., and Bilgin, Z. (1998). Customer-Service Provide Relationships: An Empirical Test of a Model of Service Quality, Satisfaction and Relationship Oriented Outcome. International Journal of Service Industry Management, 9(2), 155-168. http://dx.doi.org/10.1108/09564239810210505

Swar, B.N., and Sahoo, P.K. (2012). Service quality. Public, Private, and Foreign Banks. Journal of Indian Management, 9(3), 43-51. 
Uddin, M., and Akhter, B., (2012). Determinants of Customer Satisfaction of Banking Industry in Bangladesh. Pakistan Journal of Commerce \& Social Sciences, 6(2), 242-256.

Wieseke, J., Geigenmüller, A., and Kraus, F. (2012). On the Role of Empathy in Customer Employee Interactions. Journal of Service Research, 15(3), 316-331. http://dx.doi.org/10.1177/1094670512439743

Yeh, Y. (2013). The impact of Customer Advocacy on Customer perceived value. Journal of Business and Retail Management Research (JBRMR), 8(1), 91-102.

Zairi, M. (2000). Managing Customer Satisfaction: A Best Practice Perspective. The TQM Magazine, 12(6), 389-494. http://dx.doi.org/10.1108/09544780010351670

Zeithaml, V.A., Berry, L.L. and Parasuraman, A. (1996). The Behavioral Consequences of Service Quality. Journal of Marketing, 60, 31-46. http://dx.doi.org/10.2307/1251929

Zeithaml, V.A., Bitner, M.J. and Grembler, D.D. (2006). Service Marketing. Integrating Customer Focus across the Firm. Fourth Edition. McGraw-Hill/Irwin.

Zeithaml,V.A., and Parasuraman, A. (2004), Service Quality. MSI Relevant Knowledge Series Cambridge. MA: Marketing Science Institute.

Zeithmal, V.A. (1988). Consumer Perceptions of Price, Quality and Value: A Means-End Model and Synthesis of Evidence. Journal of Marketing, 52(3), 2-22. http://dx.doi.org/10.2307/1251446

\section{Appendix}

SERVEQUAL (To measure perceived service quality)

\begin{tabular}{|c|c|c|c|c|c|c|}
\hline \# & QUESTION & \multicolumn{5}{|l|}{ ANSWER } \\
\hline & \multicolumn{6}{|l|}{ TANGIBLES } \\
\hline 1. & $\begin{array}{l}\text { The bank has } \\
\text { modern-looking } \\
\text { equipment's. }\end{array}$ & $\begin{array}{l}\text { STRONGLY } \\
\text { AGREE }\end{array}$ & AGREE & $\begin{array}{l}\text { NEITHER } \\
\text { AGREE OR } \\
\text { DISAGREE }\end{array}$ & DISAGREE & $\begin{array}{l}\text { STRONGLY } \\
\text { DISAGREE }\end{array}$ \\
\hline 2. & $\begin{array}{l}\text { The physical facilities at } \\
\text { the bank are usually } \\
\text { appealing }\end{array}$ & $\begin{array}{l}\text { STRONGLY } \\
\text { AGREE }\end{array}$ & AGREE & $\begin{array}{l}\text { NEITHER } \\
\text { AGREE OR } \\
\text { DISAGREE }\end{array}$ & DISAGREE & $\begin{array}{l}\text { STRONGLY } \\
\text { DISAGREE }\end{array}$ \\
\hline 3. & $\begin{array}{l}\text { Employees at the bank } \\
\text { are neat- appearing }\end{array}$ & $\begin{array}{l}\text { STRONGLY } \\
\text { AGREE }\end{array}$ & AGREE & $\begin{array}{l}\text { NEITHER } \\
\text { AGREE OR } \\
\text { DISAGREE }\end{array}$ & DISAGREE & $\begin{array}{l}\text { STRONGLY } \\
\text { DISAGREE }\end{array}$ \\
\hline 4. & $\begin{array}{l}\text { Materials associated with } \\
\text { the bank (such as } \\
\text { website, statements, } \\
\text { etc...) are usually } \\
\text { appealing }\end{array}$ & $\begin{array}{l}\text { STRONGLY } \\
\text { AGREE }\end{array}$ & AGREE & $\begin{array}{l}\text { NEITHER } \\
\text { AGREE OR } \\
\text { DISAGREE }\end{array}$ & DISAGREE & $\begin{array}{l}\text { STRONGLY } \\
\text { DISAGREE }\end{array}$ \\
\hline \# & QUESTION & \multicolumn{5}{|l|}{ Answer } \\
\hline & \multicolumn{6}{|l|}{ RELIABILITY } \\
\hline
\end{tabular}




\section{Macrothink}

Journal of Management Research

ISSN 1941-899X

2015, Vol. 7, No. 1

\begin{tabular}{|c|c|c|c|c|c|c|}
\hline 1. & $\begin{array}{l}\text { When the bank promises } \\
\text { to do something by a } \\
\text { certain time, they do so }\end{array}$ & $\begin{array}{l}\text { STRONGLY } \\
\text { AGREE }\end{array}$ & AGREE & $\begin{array}{l}\text { NEITHER } \\
\text { AGREE OR } \\
\text { DISAGREE }\end{array}$ & DISAGREE & $\begin{array}{l}\text { STRONGLY } \\
\text { DISAGREE }\end{array}$ \\
\hline 2. & $\begin{array}{l}\text { When customers have a } \\
\text { problem, the bank } \\
\text { shows a sincere interest } \\
\text { in solving it }\end{array}$ & $\begin{array}{l}\text { STRONGLY } \\
\text { AGREE }\end{array}$ & AGREE & $\begin{array}{l}\text { NEITHER } \\
\text { AGREE OR } \\
\text { DISAGREE }\end{array}$ & DISAGREE & $\begin{array}{l}\text { STRONGLY } \\
\text { DISAGREE }\end{array}$ \\
\hline 3. & $\begin{array}{l}\text { The bank does provide } \\
\text { their services at time they } \\
\text { promise }\end{array}$ & $\begin{array}{l}\text { STRONGLY } \\
\text { AGREE }\end{array}$ & AGREE & $\begin{array}{l}\text { NEITHER } \\
\text { AGREE OR } \\
\text { DISAGREE }\end{array}$ & DISAGREE & $\begin{array}{l}\text { STRONGLY } \\
\text { DISAGREE }\end{array}$ \\
\hline 4. & $\begin{array}{l}\text { The bank performs the } \\
\text { service right the first } \\
\text { time }\end{array}$ & $\begin{array}{l}\text { STRONGLY } \\
\text { AGREE }\end{array}$ & AGREE & $\begin{array}{l}\text { NEITHER } \\
\text { AGREE OR } \\
\text { DISAGREE }\end{array}$ & DISAGREE & $\begin{array}{l}\text { STRONGLY } \\
\text { DISAGREE }\end{array}$ \\
\hline 5. & $\begin{array}{l}\text { The bank normally } \\
\text { insists on error - free } \\
\text { record }\end{array}$ & $\begin{array}{l}\text { STRONGLY } \\
\text { AGREE }\end{array}$ & AGREE & $\begin{array}{l}\text { NEITHER } \\
\text { AGREE OR } \\
\text { DISAGREE }\end{array}$ & DISAGREE & $\begin{array}{l}\text { STRONGLY } \\
\text { DISAGREE }\end{array}$ \\
\hline \multicolumn{7}{|c|}{ RESPONSIVENESS } \\
\hline 1. & $\begin{array}{l}\text { The bank employees tell } \\
\text { customers exactly when } \\
\text { service will be performed }\end{array}$ & $\begin{array}{l}\text { STRONGLY } \\
\text { AGREE }\end{array}$ & AGREE & $\begin{array}{l}\text { NEITHER } \\
\text { AGREE OR } \\
\text { DISAGREE }\end{array}$ & DISAGREE & $\begin{array}{l}\text { STRONGLY } \\
\text { DISAGREE }\end{array}$ \\
\hline 2. & $\begin{array}{l}\text { Employees at the bank } \\
\text { give prompt service to } \\
\text { customers }\end{array}$ & $\begin{array}{l}\text { STRONGLY } \\
\text { AGREE }\end{array}$ & AGREE & $\begin{array}{l}\text { NEITHER } \\
\text { AGREE OR } \\
\text { DISAGREE }\end{array}$ & DISAGREE & $\begin{array}{l}\text { STRONGLY } \\
\text { DISAGREE }\end{array}$ \\
\hline 3. & $\begin{array}{l}\text { Employees at the bank } \\
\text { are always willing to } \\
\text { help customers }\end{array}$ & $\begin{array}{l}\text { STRONGLY } \\
\text { AGREE }\end{array}$ & AGREE & $\begin{array}{l}\text { NEITHER } \\
\text { AGREE OR } \\
\text { DISAGREE }\end{array}$ & DISAGREE & $\begin{array}{l}\text { STRONGLY } \\
\text { DISAGREE }\end{array}$ \\
\hline 4. & $\begin{array}{l}\text { Employees of the bank } \\
\text { are never too busy to } \\
\text { respond to customers' } \\
\text { request }\end{array}$ & $\begin{array}{l}\text { STRONGLY } \\
\text { AGREE }\end{array}$ & AGREE & $\begin{array}{l}\text { NEITHER } \\
\text { AGREE OR } \\
\text { DISAGREE }\end{array}$ & DISAGREE & $\begin{array}{l}\text { STRONGLY } \\
\text { DISAGREE }\end{array}$ \\
\hline \multicolumn{7}{|c|}{ ASSURANCE } \\
\hline 1. & $\begin{array}{l}\text { The behaviors of the } \\
\text { bank employees instill } \\
\text { confidence in customers }\end{array}$ & $\begin{array}{l}\text { STRONGLY } \\
\text { AGREE }\end{array}$ & AGREE & $\begin{array}{l}\text { NEITHER } \\
\text { AGREE OR } \\
\text { DISAGREE }\end{array}$ & DISAGREE & $\begin{array}{l}\text { STRONGLY } \\
\text { DISAGREE }\end{array}$ \\
\hline 2. & $\begin{array}{l}\text { Customers of the bank } \\
\text { feel safe in their } \\
\text { transactions }\end{array}$ & $\begin{array}{l}\text { STRONGLY } \\
\text { AGREE }\end{array}$ & AGREE & $\begin{array}{l}\text { NEITHER } \\
\text { AGREE OR } \\
\text { DISAGREE } \\
\end{array}$ & DISAGREE & $\begin{array}{l}\text { STRONGLY } \\
\text { DISAGREE }\end{array}$ \\
\hline 3. & $\begin{array}{l}\text { Employees of the bank } \\
\text { are consistently } \\
\text { courteous with customers }\end{array}$ & $\begin{array}{l}\text { STRONGLY } \\
\text { AGREE }\end{array}$ & AGREE & $\begin{array}{l}\text { NEITHER } \\
\text { AGREE OR } \\
\text { DISAGREE } \\
\end{array}$ & DISAGREE & $\begin{array}{l}\text { STRONGLY } \\
\text { DISAGREE }\end{array}$ \\
\hline$\#$ & QUESTION & Answer & & & & \\
\hline 4. & Employees at the bank & STRONGLY & AGREE & NEITHER & DISAGREE & STRONGLY \\
\hline
\end{tabular}




\section{Macrothink}

Journal of Management Research

ISSN 1941-899X

2015, Vol. 7, No. 1

\begin{tabular}{|l|l|l|l|l|l|l|}
\hline & $\begin{array}{l}\text { have the knowledge to } \\
\text { answer } \\
\text { questions }\end{array}$ & AGREE & \multicolumn{2}{|l|}{$\begin{array}{l}\text { AGREE OR } \\
\text { DISAGREE }\end{array}$} & DISAGREE \\
\hline 1. & $\begin{array}{l}\text { The bank give } \\
\text { customers individual } \\
\text { attention }\end{array}$ & $\begin{array}{l}\text { STRONGLY } \\
\text { AGREE }\end{array}$ & AGREE & $\begin{array}{l}\text { NEITHER } \\
\text { AGREE OR } \\
\text { DISAGREE }\end{array}$ & DISAGREE & $\begin{array}{l}\text { STRONGLY } \\
\text { DISAGREE }\end{array}$ \\
\hline 2. & $\begin{array}{l}\text { The bank has operating } \\
\text { hours convenient to all } \\
\text { their customers }\end{array}$ & $\begin{array}{l}\text { STRONGLY } \\
\text { AGREE }\end{array}$ & AGREE & $\begin{array}{l}\text { NEITHER } \\
\text { AGREE OR } \\
\text { DISAGREE }\end{array}$ & DISAGREE & $\begin{array}{l}\text { STRONGLY } \\
\text { DISAGREE }\end{array}$ \\
\hline 4. & $\begin{array}{l}\text { The bank has customers' } \\
\text { best interest at heart }\end{array}$ & $\begin{array}{l}\text { STRONGLY } \\
\text { AGREE }\end{array}$ & AGREE & $\begin{array}{l}\text { NEITHER } \\
\text { AGREE OR } \\
\text { DISAGREE }\end{array}$ & DISAGREE & $\begin{array}{l}\text { STRONGLY } \\
\text { DISAGREE }\end{array}$ \\
\hline 5. & $\begin{array}{l}\text { The bank understands } \\
\text { the specific needs of their } \\
\text { customers }\end{array}$ & $\begin{array}{l}\text { STRONGLY } \\
\text { AGREE }\end{array}$ & AGREE & $\begin{array}{l}\text { NEITHER } \\
\text { AGREE OR } \\
\text { DISAGREE }\end{array}$ & DISAGREE & $\begin{array}{l}\text { STRONGLY } \\
\text { DISAGREE }\end{array}$ \\
\hline
\end{tabular}

(To measure customer satisfaction)

\begin{tabular}{|c|c|c|c|c|c|c|}
\hline \# & QUESTION & ANSWER & & & & \\
\hline 1. & $\begin{array}{l}\text { I am satisfied with my } \\
\text { decision to use the } \\
\text { services of the bank }\end{array}$ & $\begin{array}{l}\text { STRONGLY } \\
\text { AGREE }\end{array}$ & AGREE & $\begin{array}{l}\text { NEITHER } \\
\text { AGREE OR } \\
\text { DISAGREE }\end{array}$ & DISAGREE & $\begin{array}{l}\text { STRONGLY } \\
\text { DISAGREE }\end{array}$ \\
\hline 2. & $\begin{array}{l}\text { If I were to do it again, I } \\
\text { would feel differently } \\
\text { about dealing with the } \\
\text { bank }\end{array}$ & $\begin{array}{l}\text { STRONGLY } \\
\text { AGREE }\end{array}$ & AGREE & $\begin{array}{l}\text { NEITHER } \\
\text { AGREE OR } \\
\text { DISAGREE }\end{array}$ & DISAGREE & $\begin{array}{l}\text { STRONGLY } \\
\text { DISAGREE }\end{array}$ \\
\hline 3. & $\begin{array}{l}\text { My choice to deal with the } \\
\text { bank was a wise one }\end{array}$ & $\begin{array}{l}\text { STRONGLY } \\
\text { AGREE }\end{array}$ & AGREE & $\begin{array}{l}\text { NEITHER } \\
\text { AGREE OR } \\
\text { DISAGREE }\end{array}$ & DISAGREE & $\begin{array}{l}\text { STRONGLY } \\
\text { DISAGREE }\end{array}$ \\
\hline 4. & $\begin{array}{l}\text { I am not happy with my } \\
\text { earlier decision to deal } \\
\text { with the bank }\end{array}$ & $\begin{array}{l}\text { STRONGLY } \\
\text { AGREE }\end{array}$ & AGREE & $\begin{array}{l}\text { NEITHER } \\
\text { AGREE OR } \\
\text { DISAGREE }\end{array}$ & DISAGREE & $\begin{array}{l}\text { STRONGLY } \\
\text { DISAGREE }\end{array}$ \\
\hline 5. & $\begin{array}{l}\text { I think I did the right thing } \\
\text { by deciding to use the } \\
\text { services of the bank }\end{array}$ & $\begin{array}{l}\text { STRONGLY } \\
\text { AGREE }\end{array}$ & AGREE & $\begin{array}{l}\text { NEITHER } \\
\text { AGREE OR } \\
\text { DISAGREE }\end{array}$ & DISAGREE & $\begin{array}{l}\text { STRONGLY } \\
\text { DISAGREE }\end{array}$ \\
\hline 6. & $\begin{array}{l}\text { My experience of dealing } \\
\text { with the bank was very } \\
\text { unsatisfactory }\end{array}$ & $\begin{array}{l}\text { STRONGLY } \\
\text { AGREE }\end{array}$ & AGREE & $\begin{array}{l}\text { NEITHER } \\
\text { AGREE OR } \\
\text { DISAGREE }\end{array}$ & DISAGREE & $\begin{array}{l}\text { STRONGLY } \\
\text { DISAGREE }\end{array}$ \\
\hline
\end{tabular}

\section{Copyright Disclaimer}

Copyright for this article is retained by the author(s), with first publication rights granted to the journal. 